\title{
Apples, oranges and lemons: public sector debt statistics in the 21 st century
}

Mike Seiferling(1)

\author{
Correspondence: m.seiferling@ud. \\ ac.uk \\ School of Public Policy, University \\ College London, London, UK
}

\begin{abstract}
In both academic research and policymaking, public sector debt and debt-to-GDP ratios are relied on for a multitude of important economic, political and socioeconomic decisions, especially as public sector balance sheets expand to an unprecedented size in the midst of the 2019-2020 COVID pandemic. The reliance on available data from reputable sources often overlooks the question of whether the denominator in this ratio is accurately measured or how well the denominator is understood by the audience interpreting it. Building on past work in international financial statistics, and making use of a unique and newly created dataset on media reporting of public sector debt, the purpose of this article is to examine the quality, accuracy, interpretation and overall meaningfulness of public sector financial statistics. The main findings suggest that i) most of the world's governments still do not seem to feel sufficient pressure to voluntarily provide comprehensive financial statistics based on well-defined modern methodological frameworks and ii) high profile financial statistics, which are reported, have become increasingly numerous and complicated, making it difficult for non-experts to know which is most appropriate in the context of their analysis.
\end{abstract}

Keywords: Public finance statistics, Economic measurement, Public debt, Government debt, Politics of statistics

JEL classification: $\mathrm{H1}, \mathrm{H} 3, \mathrm{H} 6, \mathrm{H} 7, \mathrm{G} 3, \mathrm{M} 4, \mathrm{~F} 5$

\section{Springer Open}

\section{Introduction}

In July of 1990, William Easterly and Stanley Fischer published a short article in the World Bank Research Observer entitled 'The Economics of the Government Budget Constraint', which ended with a one-page appendix on 'Problems of Measurement' and began with the sentence:

"International comparisons of fiscal data are plagued by the variations in methodology and the lack of comprehensive coverage of the public sector. Definitions of deficits change from country to country and even over time in the same country." (Easterly and Fisher 1990)

Less than 1 year later, in 1991, Mario Blejer and Adrienne Cheasty published a fairly extensive review of analytical and methodological approaches to measuring fiscal deficits, ranging from accounting principles covered in national accounts methodology to

(c) The Author(s). 2020 Open Access This article is licensed under a Creative Commons Attribution 4.0 International License, which permits use, sharing, adaptation, distribution and reproduction in any medium or format, as long as you give appropriate credit to the original author(s) and the source, provide a link to the Creative Commons licence, and indicate if changes were made. The images or other third party material in this article are included in the article's Creative Commons licence, unless indicated otherwise in a credit line to the material. If material is not included in the article's Creative Commons licence and your intended use is not permitted by statutory regulation or exceeds the permitted use, you will need to obtain permission directly from the copyright holder. To view a copy of this licence, visit http://creativecommons.org/licenses/by/4.0/. 
their economic interpretation and meaning (Blejer and Cheasty 1991, also see Kotlikoff 1988). It seemed, in the early 1990 s, that mainstream economics was beginning to take measurement issues in public sector financial data more seriously.

Thirty years after the publication of these articles, with significant advances being made in terms of technological, methodological and statistical knowledge in the broad field of financial accounting, researchers, policymakers and media outlets may have reasonably expected to raise the bar on the quality and comprehensiveness when it came to the communication of financial statistics, especially where they have meaningful impacts on policy outcomes and/or the wider public's opinion regarding a government's management of the public purse. Additionally, it should be expected that communication of public sector financial statistics such as government debt, in high quality journals, government reports and media stories would consider the possibility that they were comparing apples, oranges or lemons prior to advertising simple comparisons or generalized parametric results ('garbage-in, garbage-out'). Focusing on 'government' or 'public sector' debt, the purpose of this article is to explore theoretical and empirical issues that continue to plague the availability, usability and meaning of public finance data in 2020. The results suggest that public sector financial statistics still lack transparency and consistency in most countries, especially in the case of public corporations that make up very large proportions of the economy in many emerging and developing countries. Additionally, for countries that are prolific financial statistics reporters, these have taken on a variant of 'Goodhart's Law', ' where indicators that become important benchmarks adapt a wide variety of definitions to dilute or confuse the meaning of any single number or definition.

The remainder of this article is structured as follows: Section II will provide a short overview of the measurement and interpretation of public sector financial statistics, including a discussion of the implications concerning economic and financial analysis. Section III will discuss the mixed methods used in the article, including an international comparison of public finance statistics from a variety of international databases and a quantitative analysis of media articles in the UK focusing on debt, using a newly created dataset. Section IV will discuss the results from both the case studies of international public finance statistics and regression results from the new dataset. Section $\mathrm{V}$ will consider some the political implications that come with the low levels of reporting and draw conclusions from the discussions.

Theoretical framework: measurement and interpretation public sector financial statistics

\section{What is the public sector?}

Since its formal inception in the early twentieth century Great Depression era, the national accounts community has continued to provide clear methodological guidelines for the economically/socially important distinctions between public sector corporations (central banks, public banks, government-controlled utilities, etc.) and the general government (central/sub-national/social security funds). In fact, the international benchmark System of National Accounts (SNA) and IMF Manual on Government Finance Statistics (GFSM) have both been updated twice (1993 and 2008; 2001 and 2014, respectively) since the publication of the articles mentioned at the beginning of this

${ }^{1}$ See Goodhart 1975. 
article. From this technical perspective, modern foundations break down the public sector as broadly consisting of four independent sets of institutions: $i$ ) central government, ii) local/state governments, iii) social security funds and $i v$ ) public corporations (nonfinancial and financial SOEs). Figure 1 shows a simple illustrative breakdown of the public sector based on modern international standards (United Nations, 2009, Eurostat 2013).

Differences in institutional constraints and actor objectives within the public sector will be particularly pronounced in large and diverse countries with significant government involvement in the market economy. For example, the minister of sports will very likely have very different objectives as compared with the mayor of a small village or a board member of the government-controlled electricity corporation or the fund manager for a public social security fund. Because of this heterogeneity, some experts have argued that "... the public sector environment is itself so highly heterogeneous that it cannot be treated as one for accounting purposes, and generalizations cannot be made which embrace the whole of the sector" (Barton 1999). Looking at Fig. 1, it is evident that the use of consolidated public sector statistics may have no meaningful economic or political interpretation and should be rarely used in media, academic or time series analytical work.

Measurement and interpretation of the public sector is further complicated by its sheer volume: " ... appropriate and adequate accounting for state and local government units involves a far more complex set of interrelationships, to be reported to a more diverse set of users with a greater variety of interests and needs than exists in business accounting and reporting" (Mautz 1981). Some examples for general government are the United States, in which there exist 50 state governments and approximately $90,000^{2}$ local governments, and China, in which there are approximately 678,500 villages. ${ }^{3}$ In the case of the latter, this volume grows significantly when we consider the other side of the public sector, government-controlled corporations (Benito, Goldeng, and Grunfeld 2008; Boycko, Shleifer, and Vishny 1996; Bruton, Peng, Ahlstrom, Stan, and Xu 2015; Caprio, Fiecher, litan, and Pomerleano 2004). ${ }^{4}$

In short, to characterize 'government' or 'the public sector' as one homogenous unit-as is often done in empirical and theoretical work-with the same motivation, capacity, methodology and overall objective, defies a large collection of empirical evidence. For example, within the political science/political economy literature, there exists a vast amount of research explaining the complicated web of unique roles within government and public corporations including the important distinction and relationship between central and subnational actors and objectives (Tiebout 1956; Oates 1972; Oates 2008; Ebel and Yilmaz 2002; Rodden 2004; among many others). This can also be seen by the growth of high-quality academic journals devoted to local government over the past 20 years, along with the growing number of real-world experiments and peer-reviewed articles dedicated to fiscal decentralization.

\section{Why is this important for financial and economic analysis?}

A great deal of research has accumulated since the early 2000s, emphasizing and empirically validating the role of transparency for attracting capital, reducing fiscal risk premiums and reducing capital flight (Alesina et al. 1992; Christofides et al. 2003;

\footnotetext{
${ }^{2} 38,910$ general purpose governments, 38,266 special district governments and 12,880 public school systems.

${ }^{3}$ See IMF Government Finance Statistics Yearbook Institutional Tables (2017).

${ }^{4}$ For a more in-depth discussion of public corporations, see Appendix B.
} 


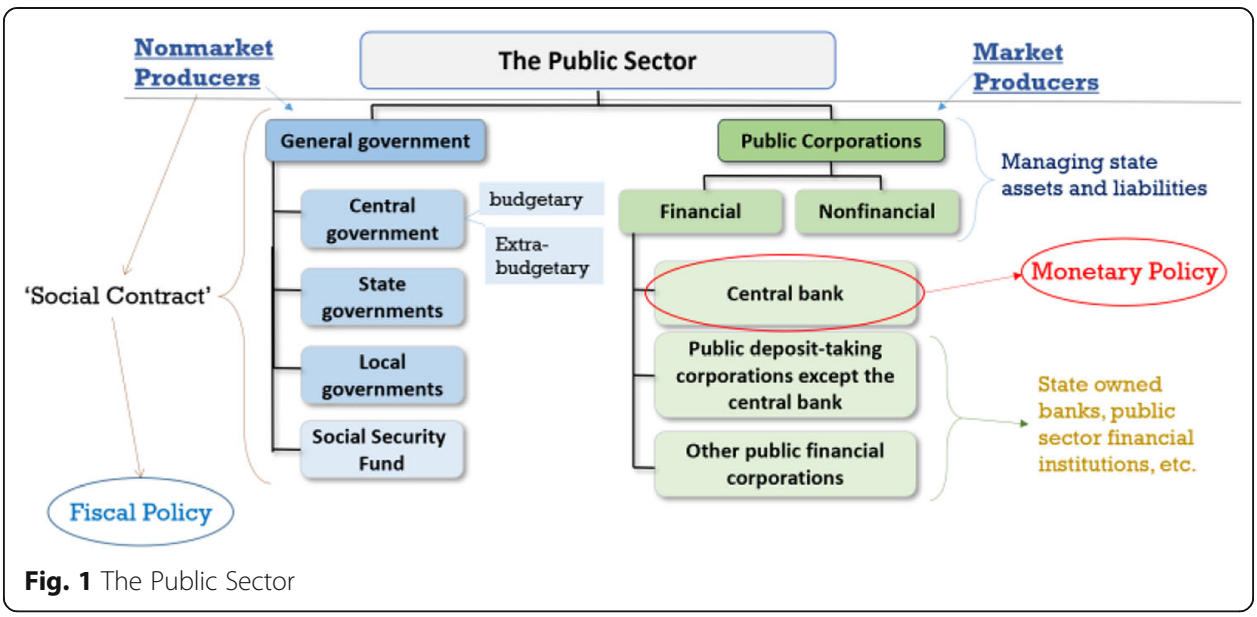

Glennerster and Shin 2003; Stockman 2004; Cady 2005; Gelos and Wei 2005; Cady and Pellechio 2006; Bernoth and Wolff 2008; Hallerberg and Wolff 2008). Uncertainties about actual levels of public sector debt can lead to a variety of unpleasant shocks to economies and subsequent downgrades from credit rating agencies. For example, a lack of transparency and uncertainties about tax collection capacity has been found to lead to higher spreads or interest payments on newly issued debt (Dell'Erba et al. 2013; Elgin and Uras 2013; Gelos and Wei 2005; Glennerster and Shin 2003; Hallerberg and Wolff 2008; Bernoth and Wolff 2008) and information asymmetries between credit rating agencies and government debt levels have been shown to lead to economic instability and have detrimental socioeconomic effects in terms of unemployment, growth rates and income inequality (Tamegawa 2016; Coccia 2017).

The accuracy and transparency of public sector debt also have implications when considering the design of sustainable fiscal systems, and adherence to and legitimacy of fiscal rules (Barro, 1974, 1979; Stockman 2001, 2004, 2010) and have been found to have a significant effect on economic growth where high debt burdens $(90 \%$ in advanced and $60 \%$ in emerging markets) have produced notably lower growth as compared with low debt burden countries (Reinhart and Rogoff 2010). Finally, the existence of several different branches within the general government and public sector, which have a variety of objectives and constraints, makes detailed and accurate financial statistics a necessity for assessing their performance and holding them accountable to the public.

These contributions suggest that transparency, consistency and comprehensiveness of public finance data are not simply an academic thought exercise but can have significant impacts on macroeconomic performance, access to international capital markets, credit ratings, adherence to fiscal rules, growth rates, incomes inequality and public sector accountability. In short, the way we compare and interpret public sector finance data makes a meaningful difference when considering economic, political and socioeconomic outcomes.

\section{Methodology}

This article adopts a mixed methods approach to examine the quality, accuracy, interpretation and overall meaningfulness of public sector debt statistics produced by national authorities. First, we look at international comparisons of debt statistics from the 
most popular data providers, focusing on the availability, consistency and quality of published data, mainly public sector debt and deficits. To do this, we draw on comparisons across a wide range of countries (Australia, Japan, Iceland, Greece, Democratic of the Congo, Venezuela, Argentina, Republic of Congo and South Africa). The case study evidence is complimented by general evidence of inconsistencies, which are provided in Appendix F.

Second, we look more closely at the communication of public sector debt statistics in the UK by focusing on the variety of official public sector debt data and how these numbers are interpreted and communicated by the media. We differentiate between primary data users and secondary data consumers. 'Primary users' (academics, policymakers, rating agencies, etc.) will likely take advantage of publicly available official information provided by the Office for National Statistics (ONS), which is regarded by international standards in terms of their methodological capacity, transparency and independence from political meddling. A wider audience of passive, 'secondary consumers' of public sector data from media outlets will more likely rely on the media to inform their opinions about the government's fiscal performance. This means that a degree of consistency should be expected between the terminology used by media outlets and the metrics they report to convey accurate messages to the public about the public sector's financial position.

To understand how accurate and consistent the language and debt data are in the UK, we coded a unique dataset with a total of 2398 news articles from 10 of the largest national media outlets over the 2008-2018 period. ${ }^{5}$ From these articles, there were over 80 different types of specific terminology used for debt, most of which can be classified into 6 main categories, as shown in Table 1.

Using these data, we ran a series of simple regressions to test $i$ ) whether there exists any media bias in terms of the level of debt reported by media outlets, and $i i$ ) whether media outlets differentiate between different definitions of debt in their articles. To estimate whether any systematic difference (media bias) exists for each of the media outlets, we ran an OLS regression with year fixed effects:

$$
\begin{aligned}
\text { debt }_{i t} & =\alpha+\rho_{t}+\beta_{1} \text { Telegraph }+\beta_{2} \text { Mail }+\beta_{3} \text { Times }+\beta_{4} \text { Express } \\
& +\beta_{5} \text { Independent }+\beta_{6} \text { Guardian }+\beta_{7} \text { Mirror }+\beta_{8} \text { Sun }
\end{aligned}
$$

where $d e b t_{i t}$ is the reported debt figure (in Bn pounds) for media outlet $i$ at time $t$; Telegraph, Mail, Times, Express, Independent, Guardian, Mirror, Sun are dummy variables identifying the reporter of debt; $\alpha$ is our benchmark (intercept) representing other media outlets from those mentioned above; $\rho_{t}$ captures year fixed effects and $\beta_{1}, \beta_{2}, \beta_{3}$, $\beta_{4}, \beta_{5}, \beta_{6}, \beta_{7}, \beta_{8}$ are unknown parameters to be estimated representing potential media bias.

The results allow for a test of whether systematic differences exist between media outlets when reporting debt statistics:

$$
H_{o 1}: \beta_{1}=\beta_{2}=\beta_{3}=\beta_{4}=\beta_{5}=\beta_{6}=\beta_{7}=\beta_{8} \text { (no media bias) }
$$

${ }^{5}$ The Daily Telegraph (626 articles), Daily Mail (584 articles), The Times (311 articles), The Express (212 articles), The Independent (201 articles), The Guardian (178 articles), Daily Mirror (122 articles), The Sun (110 articles), Daily Star (25 articles), and the Observer (24 articles). 
Table 1 Terminology and number of articles on government/public sector debt (2008-2018). (Bn Pounds and \%GDP)

\begin{tabular}{llll}
\hline Terminology & Articles & Mean debt (bn) & Standard deviation \\
\hline 'National Debt' (Bn) & 1218 & 1301.2 & 666.4 \\
'National Debt' (\%GDP) & 439 & 72.6 & 21.9 \\
'Government Debt' (Bn) & 157 & 1176.8 & 448.5 \\
'Government Debt' (\%GDP) & 133 & 72.8 & 24.9 \\
'Public Debt' (Bn) & 125 & 1088.2 & 426.7 \\
'Public Debt' (\%GDP) & 123 & 69.3 & 17.9 \\
'Public Net Debt' (Bn) & 96 & 1270.5 & 911.8 \\
'Public Net Debt' (\%GDP) & 77 & 66.4 & 17.0 \\
'Country's Debt' (Bn) & 52 & 1428.1 & 361.3 \\
'Country's Debt' (\%GDP) & 36 & 84.5 & 80.4 \\
'Net Debt' (Bn) & 26 & 1006.0 & 328.5 \\
'Net Debt' (\%GDP) & 30 & 56.6 & 16.6 \\
\hline
\end{tabular}

$H_{A 1}: \beta_{1} \neq \beta_{2} \neq \beta_{3} \neq \beta_{4} \neq \beta_{5} \neq \beta_{6} \neq \beta_{7} \neq \beta_{8}$ (media bias)

Moving to the terminology used by media outlets, we can test for whether differences are taken into account when reporting 'national', 'public', 'government', 'country' and 'public net' debt statistics:

$$
\text { debt }_{i t}=\alpha+\rho_{t}+\gamma_{1} \text { national }+\gamma_{2} \text { public }+\gamma_{3} \text { government }+\gamma_{4} \text { country }
$$

where debt $_{i t}$ is the reported debt figure (in Bn pounds) for media outlet $i$ at time $t$; national, public, government, country are dummy variables recording the reporter of debt; $\alpha$ is our benchmark (intercept) representing net public debt; $\rho_{t}$ captures year fixed effects and $\gamma_{1}, \gamma_{2}, \gamma_{3}, \gamma_{4}$ are unknown parameters to be estimated.

The results allow for a test of whether systematic differences exist within media outlets when using different terminology relating to debt statistics:

$H_{o 2}: \gamma_{1}=\gamma_{2}=\gamma_{3}=\gamma_{4}$ (no differentiation between different terminology)

$H_{A 2}: \gamma_{1} \neq \gamma_{2} \neq \gamma_{3} \neq \gamma_{4}$ (differentiation between different terminology)

\section{Results}

\section{International comparison of public sector debt}

Previous studies on data comparability from different international organizations characterized some of the differences that emerged as requiring "Herculean investigating to understand" (Bloch and Fall 2015). These critiques are not unique to any one national government or international organization as inconsistencies can be found across all sources. In Herrera and Kapur (2007), they find that

"The IMF's primary statistical publication, International Financial Statistics, provides many instances where the data of the same year in books from different years do not match. Similarly, there are sometimes unexplained discrepancies between the print and electronic versions. This problem is by no means unique to the IMF. The World Bank offers data on GNP per capita growth rates for countries where underlying GNP data do not exist; they also report the share of agriculture in GDP for countries with non-existent GDP estimates." (Kapur et al. 1997) 
More recent work on balance of payments statistics has concluded that "errors have persisted or grown worse despite ambitious harmonization programs", and the "best data now available are sometimes conflicting or otherwise obviously deficient and thus require cautious handling and ... may be substantially affected by the choice made between alternative data sources and by the assumptions made about the causes of observed discrepancies" (Linsi and Mügge 2019). To get an idea of the quality, comprehensiveness and transparency of public sector financial statistics, we began by looking at the most prevalent sources, including the World Bank and the IMF. ${ }^{6}$ By focusing on public sector deficits and debt, arguably the most common benchmark indicators and most cited in the media, this work can be seen as complimentary to other valuable contributions, which have focused on the quality of public debt statistics (Bloch and Fall 2015) and balance of payment statistics (Herrera and Kapur 2007; Damgaard and Elkjaer 2017; Linsi and Mügge 2019).

Three of the most popular international sources of debt statistics are the IMF's World Economic Outlook (WEO), the IMF Government Finance Statistics Yearbook (GFSY) and the World Bank's World Development Indicators (WDI). All of these databases produce relatively aggregate data for the central and general governments. As concluded in Jaimovich and Panizza (2010), the availability of government financial data from international sources remains surprisingly poor, especially in terms of comparability and comprehensiveness. This is especially true in the case of public corporations (state-owned enterprises), where comprehensive debt statistics are virtually nonexistent amongst emerging and developing countries (neither WEO nor GFSY cover public corporations). For example, in 2017, there were 38 countries reporting gross debt data for general government in GFSY, 43 countries reporting gross debt in WDI and 188 countries reporting gross debt for general government in WEO (relative to 31, 40 and 136, respectively, in 2000).

To get a better idea of the variety of definitions for government debt and comparability across databases, we looked at publicly available data for Australia, Japan, Iceland, and Greece, shown in Fig. 2 below.

The differences in reported data are surprisingly large. For example, gross debt for the Japanese general government in WEO is over 20\% of GDP larger than gross general government debt in GFSY (as discussed above) and general government gross debt is over 30\% of GDP lower in Colombia. ${ }^{7}$ The mean difference when comparing WEO and GFSY general government is $-7.1 \%$ of GDP with a large standard deviation of 8.4. ${ }^{8}$ As noted in section II, these differences can have significant impacts on analytical exercises.

Some of the differences in levels of reporting between WEO and GFSY/WDI can be explained by the different objectives, clients and purposes of these databases. ${ }^{9}$ WEO has very good availability compared with GFSY, making it more widely used in analytical work, but the data are not compiled in a systematic way and often is limited in, or unclear about, coverage. The data can be provided by a variety of sources, some of

${ }^{6}$ Note that public sector financial statistics are also available for global subsets of countries from BIS and OECD.

${ }^{7}$ See Appendix F for overall discrepancies between databases.

${ }^{8}$ Ibid. 


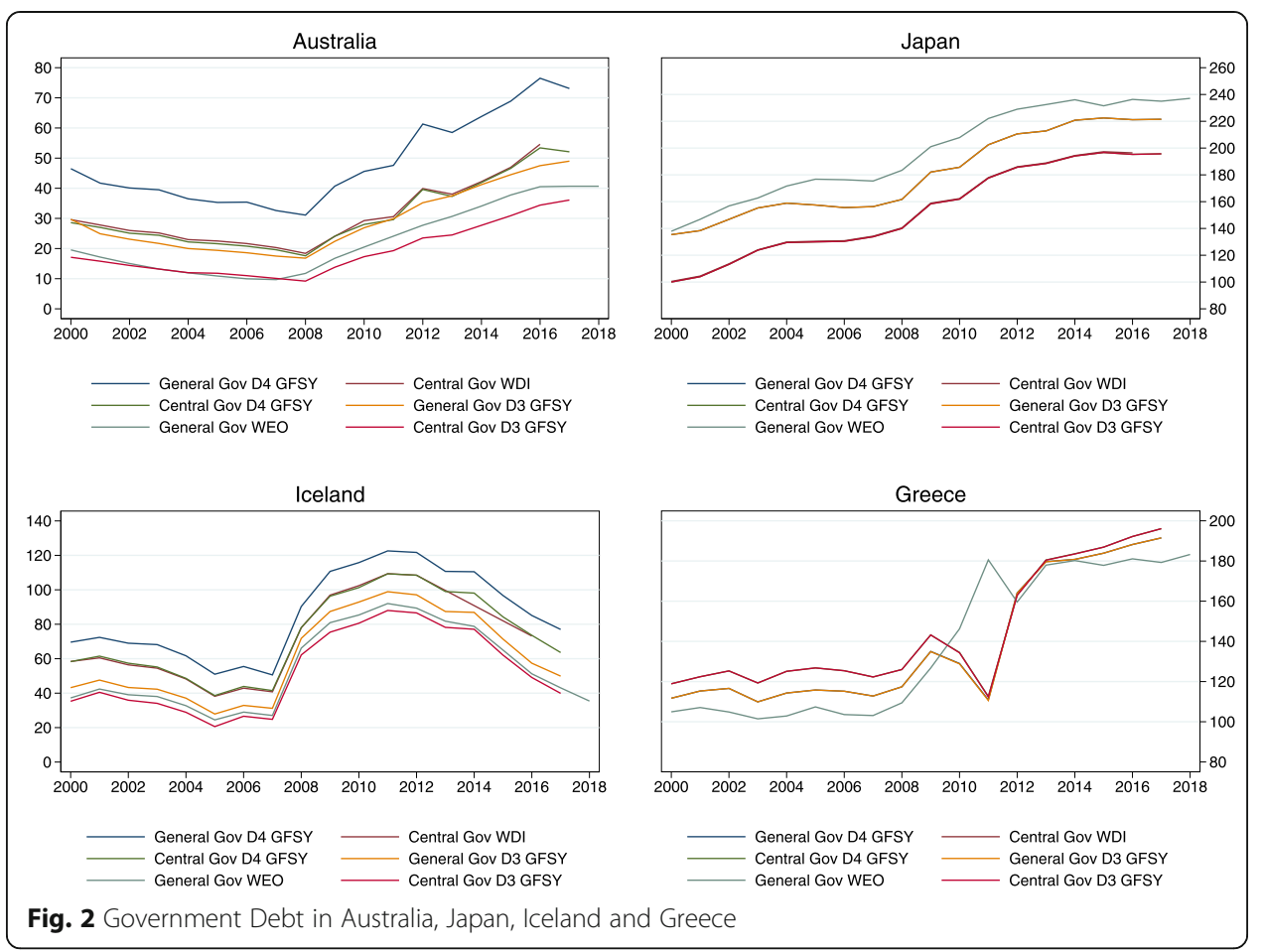

whom may lack the statistical capacity or resources to compile debt statistics according to a predefined methodology or may lack the necessary resources to do so. Government debt data from GFSY follow strong methodological guidelines but availability continues to be limited and definitions of debt become more varied and complicated. Other differences in Fig. 2 can be explained by technical details in the metadata. ${ }^{10}$ There is also the potential for data to diverge due to $i$ ) differing data sources (administrative records, individual ministries, surveys, etc.), ii) differing levels of legal backing for the collection of data, iii) adherence to differing compilation manuals, $i v$ ) differing valuation methods and accounting principles and $v$ ) differing classification of units within the public sector (Damgaard and Elkjaer 2017; Linsi and Mügge 2019). The challenge comes when nonexpert data users or media outlets compare these or report them inaccurately in the news.

\footnotetext{
${ }^{10}$ For example, as world leaders in the compilation of public finance statistics, Australia and Iceland are two of the few countries who report pension liabilities in IMF's GFSY database. This explains the large differences between D3 and D4 for both central and general government. WEO generally does consider pension liabilities as part of debt, which would explain the large differences between GFSY D4 and WEO gross debt. In the case of Japan, WEO debt data are reported on an unconsolidated basis (do not eliminate intra public sector commitments) while GFSY debt data are reported as consolidated. Noting the high level of within public sector exposures (central bank social security fund holding of government debt), unconsolidated measures will produce significantly higher levels as compared with measures, which eliminate these public sector entities. Japan is also one of the only countries in the world reporting debt on an unconsolidated basis making cross country comparisons not possible. Finally, the large discrepancy in 2011 for Greece can be explained by the valuation of debt, where WEO is valued at face value (Maastricht) and GFSY is valued at market value.

${ }^{11}$ See WEO metadata (https://www.imf.org/en/Publications/SPROLLS/world-economic-outlook-databases).

${ }^{12}$ Additional discrepancies have been found in research on data quality for DRC: "between 1981 and 1986, the IMF's GDP estimates for Zaire were about 60\% of those of the World Bank" (Herrera and Kapur 2007).
} 
Moving to some of the more conspicuous data that are not easy to explain with technical details, we looked at the four cases of the Democratic Republic of the Congo, Venezuela, Argentina and Republic of the Congo in Fig. 3. Government deficits are not always equal to changes in government debt (Seiferling 2013; Seiferling and Tareq 2015) but the two measures should, in most cases, be very closely aligned. For example, where a country runs a large deficit, we would expect that country to incur a significant amount of new debt. In the case of DRC, we can see impressive fluctuations in changes in debt over the 2000-2011 period with deficits that do not reflect these changes. In the case of Venezuela, similar trends appear with the central government running high deficits while, at the same time, paying down debt. In the case of Argentina and Republic of the Congo, there are periods where debt changes are extremely large compared with much smaller net lending/borrowing over the same periods. The metadata for these two countries describe net lending/borrowing and gross debt as coming from the same source (Ministry of Finance) and measuring the same parts of general government, making the discrepancies difficult to explain., ${ }^{112}$

For public corporations, debt data are even more scarce. Two of the most comprehensive public sector debt databases are the new IMF Public Sector Balance Sheet database (PSBS) and the World Bank Quarterly Public Sector Debt Statistics database (QPSD). Coverage from both databases is very limited with little progress in terms of the number of reporters over the 2000-2019 period. For example, in 2018, there were 26 countries reporting data for public financial corporations (including central banks) and 24 countries reporting data for nonfinancial public corporations in QPSD (relative to 21 and 19 in 2009, respectively).

As was the case with government debt data, there are large discrepancies between databases when comparing gross debt statistics for financial and nonfinancial public corporations. Figure 4 below shows available data from the IMF Public Sector Balance Sheet database and World Bank's Quarterly Public Sector Debt Statistics database for financial public corporations and nonfinancial public corporations in Japan and South Africa, where discrepancies can be as high as over 150\% of GDP.

Explaining these discrepancies is more challenging than was the case with government debt in Fig. 2. The IMF database metadata for Japanese public financial corporations state of the stock data, "Annual national accounts for 2016 published in the Cabinet Office website. No data adjustments", and the World Bank metadata for Japan state, "Data are not consolidated. Data are at Market Value." Neither of these provide any obvious clues to explain the large discrepancies in Japanese public corporation debt data. In the case of South Africa, for public financial corporations, the metadata are much more comprehensive but do not clearly explain where differences would emerge. ${ }^{13}$ The overall variation in public sector debt statistics across databases is significantly larger than those found for general government, with mean differences of $34.2 \%$ of GDP with a standard deviation of around 43.2 for public sector financial corporations and a mean difference of - 15.9\% of GDP with a standard deviation of 6.2 for public sector nonfinancial corporations.

\footnotetext{
${ }^{11}$ See WEO metadata (https://www.imf.org/en/Publications/SPROLLS/world-economic-outlook-databases).

${ }^{12}$ Additional discrepancies have been found in research on data quality for DRC: "between 1981 and 1986, the IMF's GDP estimates for Zaire were about 60\% of those of the World Bank" (Herrera and Kapur 2007). ${ }^{13}$ See Appendix C.
} 


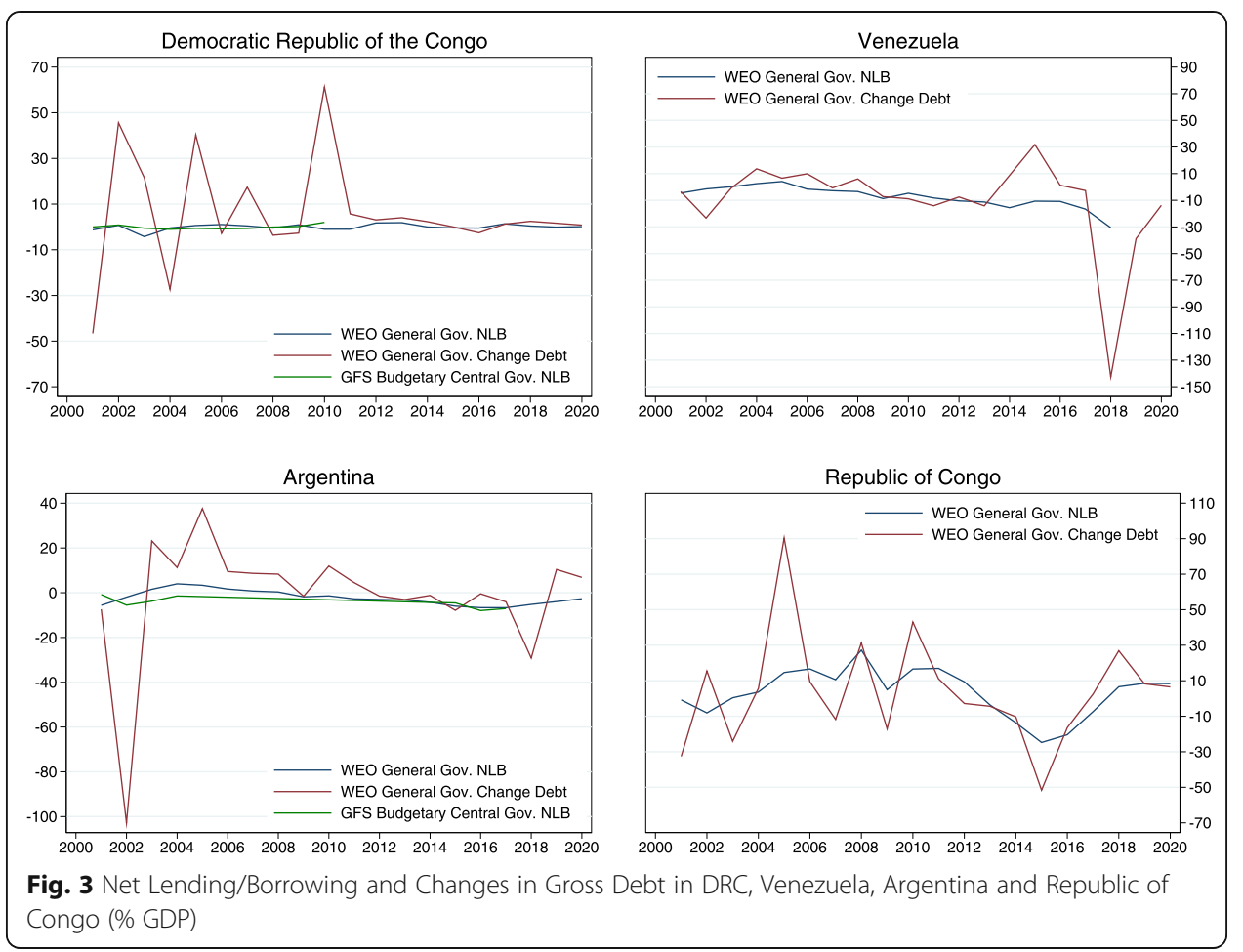

There are two major themes that emerge here. The first is the surprisingly low number of countries that produce systematic public sector financial statistics (mainly debt) based on strong methodological foundations, with little progress having been achieved over the twenty-first century for both the central government and public corporations. The quality of existing data is also questionable for some countries, given the lack of comparability and consistency. Second, for countries that do report, a variety of definitions and compilation practices allow for a wide variety of interpretations of what government or public sector debt actually is. It is this scenario that we will explore further by looking at how the wider public interprets the various definitions of public sector debt in the UK.

\section{Public sector debt statistics in the UK}

An initial challenge when assessing public sector debt in the UK from a primary perspective is the variety of definitions that exist, especially after the 2008 bailout of private sector banks and the subsequent Bank of England (BoE) creation of the Asset Purchasing Facility (APF). The complications that were created for public sector balance sheets from government nationalization of banks (RBS, NorthernRock) and BoE quantitative easing via the APF were enormous. Because of the vast expansion of public sector balance sheets, there was both a desire and analytical justification to 'redefine' public sector debt away from international benchmarks. This led to the official publication of eight different types of public sector debt that are made available to the public. ${ }^{14}$

The magnitude of differences across these definitions can be quite large, especially after 2008. Figure 5 shows the magnitude of these difference over the 1997-2019 period, comparing official ONS data with annual debt data disseminated by international organizations, mainly the IMF and the World Bank. 


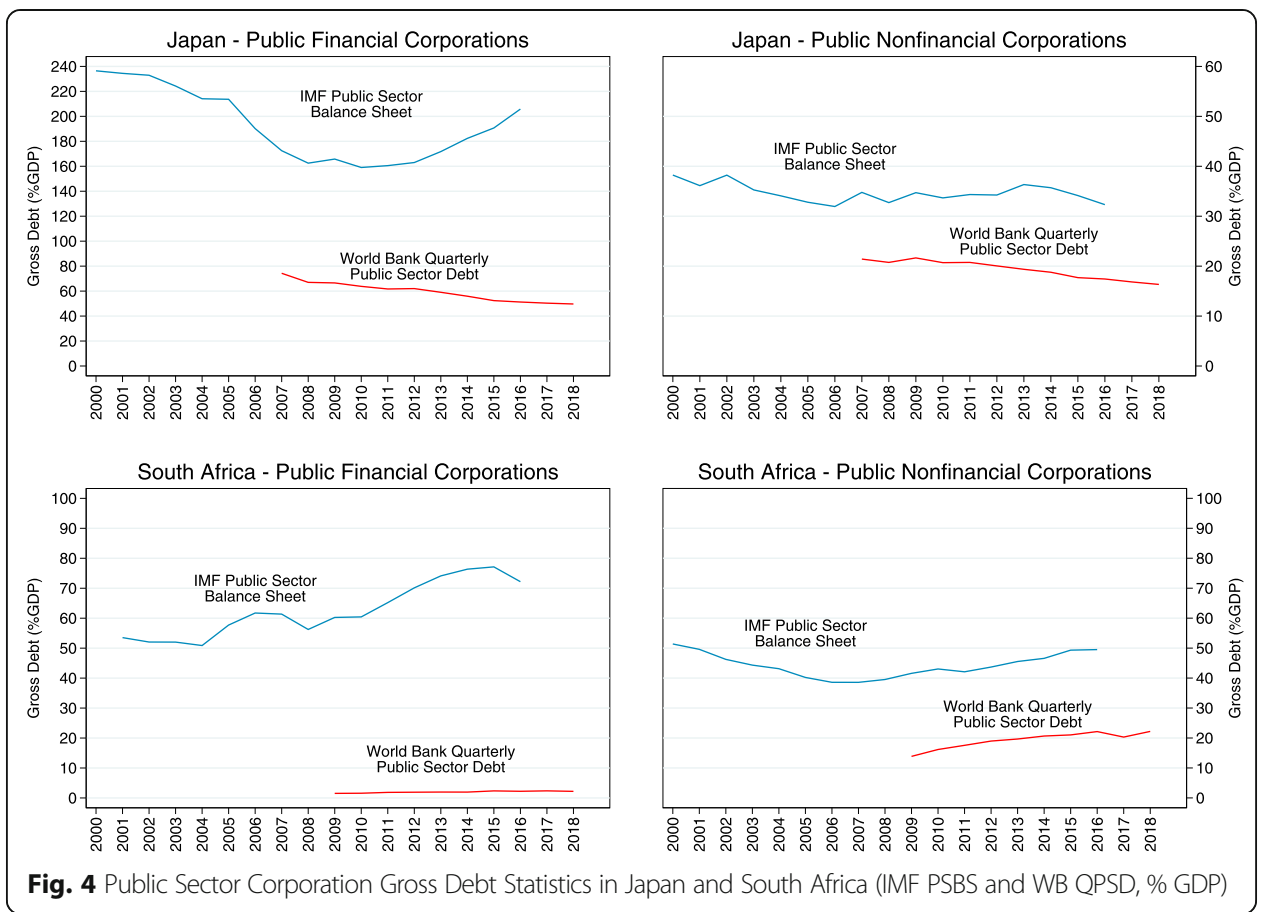

In explaining the unique presentation used by the ONS, it has been noted that "International comparisons of UK fiscal measures relating to the public sector, such as PSND, PSNFL have been established and defined by, and for use within, the UK" (ONS 2018). The challenge here comes when considering cross national comparisons and the potential for other countries to 'piggyback' on UK definitions to reduce their official debt position based on international guidelines. For example, several countries now have asset purchasing facilities like the BoE APF and may be keen to exclude the liabilities of these facilities from their debt statistics (contrary to international guidelines), even where the assets backing the debt may be toxic and worthless.

Figure 6 below shows the reported debt numbers for each of these six main terminologies over the 2008-2018 period. For reference, we also included the official gross debt of UK general government and the net debt of the entire public sector. ${ }^{15}$ It appears that the media underreported public sector debt in many cases, especially in the aftermath of the financial crisis.

While the results in Fig. 6 suggest an under-reporting of the total public sector debt in the UK, they do not appear to show any systematic differences across media outlet or types of terminology. ${ }^{16}$ We tested for the existeince of a media bias more formally using our unique database of media articles. The results for Eq. (1) are shown in Table 2 below.

These results suggest that there does not appear to be any systematic media bias when it comes to the reporting of public sector and government debt. Formally, the Ftest in all regressions fails to reject the null hypothesis $\left(H_{o 1}\right)$ that $\beta_{1}=\beta_{2}=\beta_{3}=\beta_{4}=\beta_{5}$ $=\beta_{6}=\beta_{7}=\beta_{8}$. This means that, while reporting tends to vary (see standard deviations),

\footnotetext{
${ }^{15}$ Including BoE and public financial corporations.

${ }^{16}$ See Appendix $\mathrm{G}$ and $\mathrm{H}$.
} 


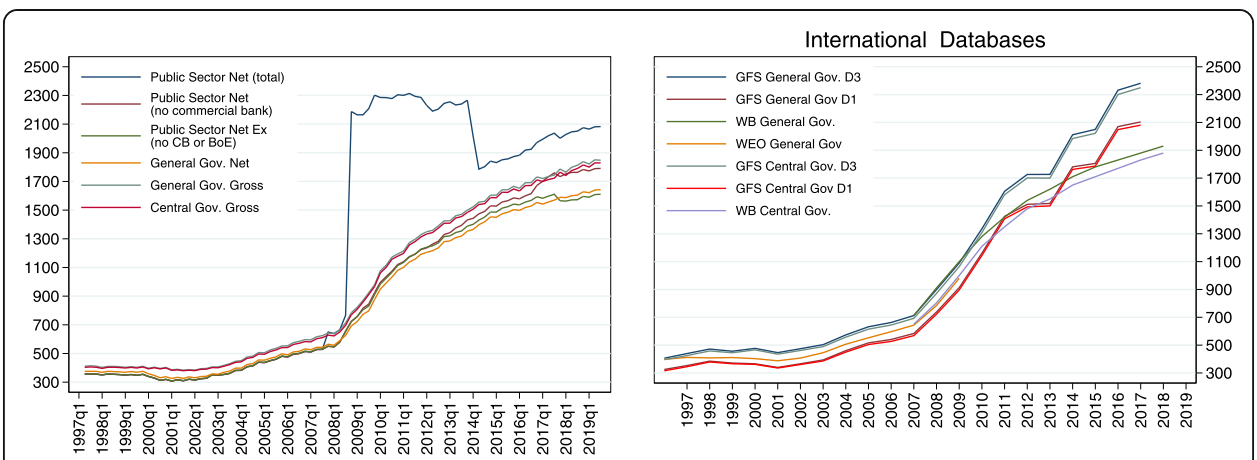

Fig. 5 Official UK Public Sector Debt Data (ONS) and Data from International Organizations. (Bn pounds)

no media outlets tend to systematically overreport or underreport the size of debt relative to other media outlets in the UK.

Moving to the test for differences across different types of terminology, the results for eq. (2) are shown in Table 3 below.

The positive news in terms of media objectivity from Table 2 is somewhat undermined by the lack of differentiation between types of public sector/government debt terminology in Table 3. Looking at our F-statistic, in four of the eight regressions, we failed to reject the null hypothesis $\left(H_{o 2}\right)$ that $\gamma_{1}=\gamma_{2}=\gamma_{3}=\gamma_{4}$ at all conventional levels of significance and, in three of the eight regressions, we would fail to reject the null at a 95\% confidence level. Given the meaningful differences in components of the public sector discussed in section II, the lack of statistical significance for these different terminologies means that media outlets do not distinguish between 'government', 'national', 'country' and 'public sector' debt, effectively treating these are synonymous. This is especially surprising given the material differences that have been highlighted throughout this article.

The overall results from our case study of the UK suggest that the variety of definitions adopted by the ONS after the financial crisis created confusion amongst data communicators. The variety of definitions also raises questions as to why the UK relies on definitions of debt that can deviate from international standards (Eurostat 2013; IMF GFSM 2014; PSDSG 2011).
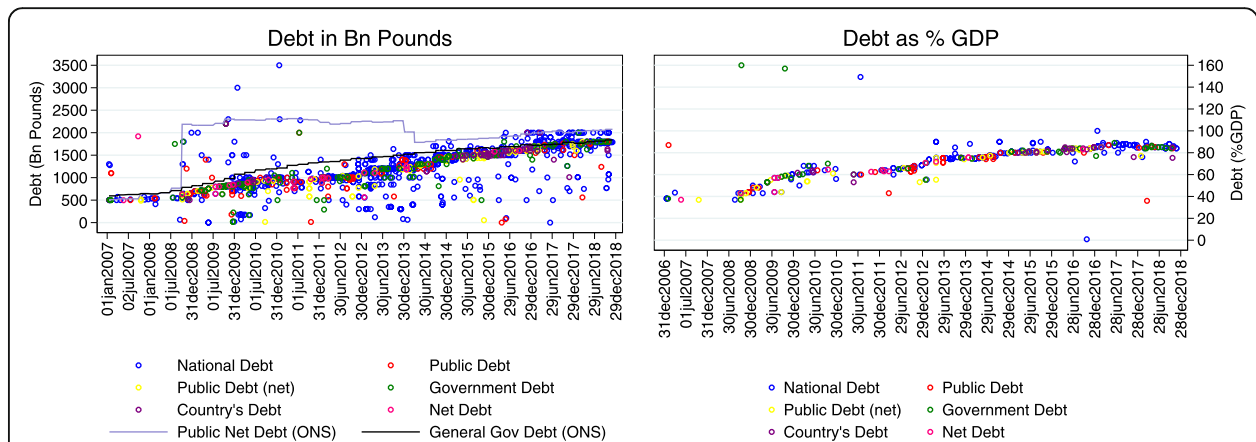

Fig. 6 Six Main Government/Public Sector debt terminologies in UK media outlets (2008-2018). (Bn Pounds and $\% \mathrm{GDP})$ 


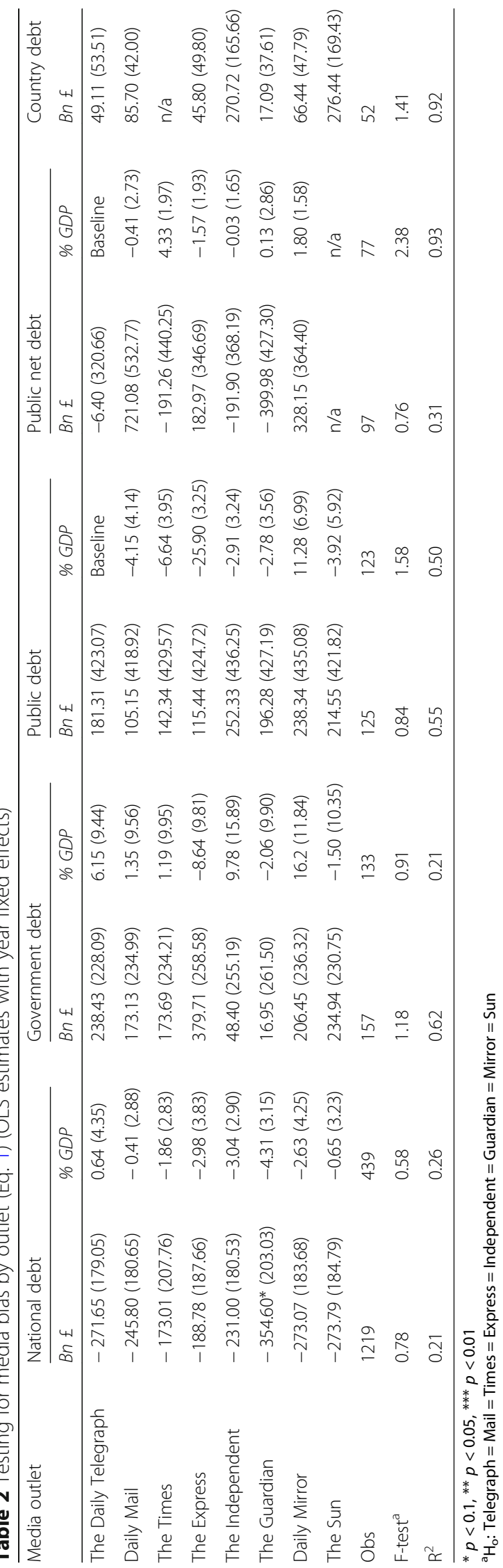




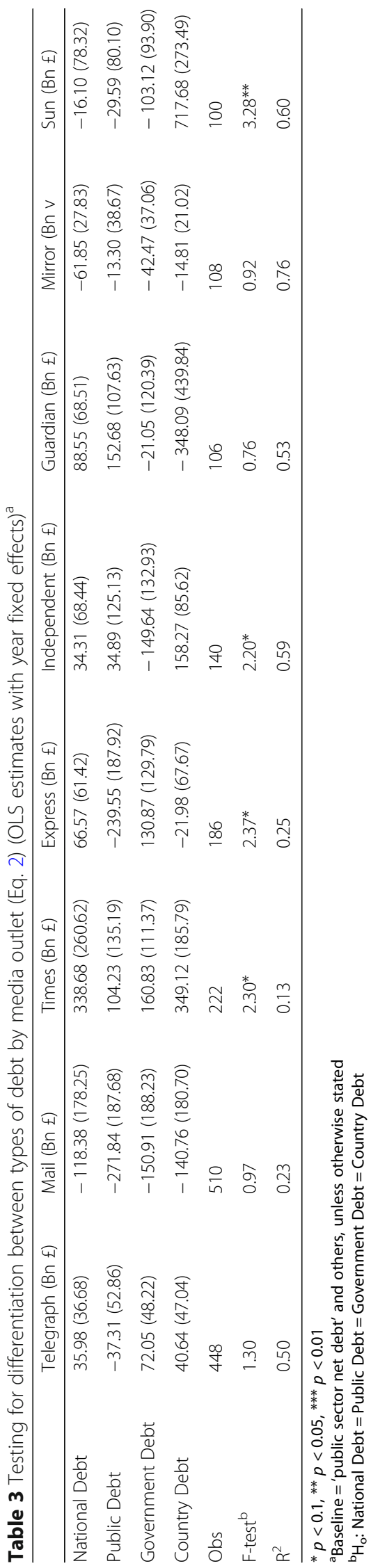




\section{Discussion and conclusion}

The results in this article raise several political, economic and socioeconomic questions. If accurate financial statistics are important for economic analysis, attracting capital, reducing risk premiums, accessing capital markets and preventing capital flight, why do problems with data quality continue to exist? Herrera and Kapur (2007) attempt to answer this question by focusing on two political factors, the incentives and capabilities of data actors. In terms of capabilities, data collection and accurate compilation are costly and complicated. Increases in the budget for statistical capacity are also not likely to sway the electorate in countries where pressing needs exists in education and infrastructure, making it difficult to finance high quality statistics. Incentive structures for producing comprehensive and accurate data are also limited, especially among politicians who make the final call on borrowing decisions. This means that, even if a country possesses a strong statistical capacity, there may also exist a culture of fear of punishment and/or material gains from reporting politically favorable statistics.

Similar political concerns have been raised in the Linsi and Mügge (2019) analysis of balance of payment statistics, finding that growing defects in financial statistics were consequential for global politics by projecting an apparent consistency of published data. This "false projection" can have important implications when considering that the IMF, World Bank, credit rating agencies can "make data driven decisions which can change nations economic fortunes" by manipulating short term access to international capital markets (Linsi and Mügge 2019). A further barrier to reliable statistics comes from the fact that statistical agencies are often not independent from government. Statistical agencies are often located within government ministries, making them prone to political meddling. This becomes problematic where a conflict of interest may exist between politicians who can gain cheap short-term access to capital markets by fabricating favorable financial statistics (until the hidden parts are discovered).

From a socioeconomic perspective, poor or fabricated data tend to produce inconsistent and misguided policy responses to real-world problems. These create not only information asymmetries between citizens and government but also information asymmetries that hamper long-term access to capital markets, and influence credit rating agencies when assessing credibility of borrowers. As noted in section II, the asymmetries have been shown to lead to economic instability and produce detrimental socioeconomic effects in terms of unemployment, growth rates and income inequality (Tamegawa 2016; Coccia 2017).

Despite a heighted attention since the early 1990s, most of the world's governments still do not seem to feel sufficient pressure to voluntarily provide comprehensive financial statistics based on well-defined modern methodological frameworks. This is especially worrying, given the increasingly large stocks of debt being built up by governments and public corporations since the 2008 financial crisis and, again, to mitigate the downturn from the COVID pandemic in 2019-2020. Creating viable solutions to this persistent problem is of heightened importance in the midst of large-scale financial transactions and public sector debt accumulation taking place in both advance and emerging/developing economies to alleviate the multitude of challenges posed by COVID. As governments and public corporations rapidly expand their balance sheets, the community of creditors and citizens who will ultimately bear the consequences of fabricated, corrupted or uncomprehensive financial statistics will need to increase the 
pressure on officials to release more accurate and reliable data and to remove political conflicts of interest by creating independent statistical institutions.

\section{Supplementary information}

Supplementary information accompanies this paper at https://doi.org/10.1186/s40854-020-00193-2.

Additional file 1: Appendix A. Public Sector Entities. Appendix B. Public Corporations. Appendix C. WEO and GFSY Metadata for Australia, Japan, Iceland, Greece. Appendix D. Public Sector Debt Metadata. Appendix E. D1 D4 definitions of debt. Appendix F. Differences in Reported Government and Public Corporation Debt Statistics between Databases. Appendix G. Sources and Composition of Measures of Public Sector Debt in the UK.

Appendix H. Debt terminologies across National Media outlet.

\section{Acknowledgements}

The author would like to thank Mr. Muhammad Septianniko Prasetio and Ms. Carolina Torres for their excellent research assistant work and Phillip Stokoe for helpful comments.

\section{Code availability}

All of the code to generate/replicate the results is available.

\section{Author's contribution}

The author carried out all of the research including the compilation and analysis of data and drafting the manuscript. The author read and approved the final manuscript.

\section{Funding}

No outside funding was received for this paper.

\section{Availability of data and materials}

The dataset on reporting of public debt in the media was coded by the authors research assistant team and can be made publicly available. All other data in the paper comes from publicly available sources and can be provided.

\section{Competing interest}

The author declares that he has no competing interest.

Received: 2 April 2020 Accepted: 12 August 2020

Published online: 30 September 2020

\section{References}

Alesina A, De Broeck M, Prati A, Tabellini G, Obstfeld M, Rebelo S (1992) Default risk on government debt in OECD countries. Econ Policy 7(15):427-463

Barro RJ (1974) Are governments bonds net wealth? J Polit Econ 82(6):1095-1117

Barro RJ (1979) On the determination of the public debt. J Polit Econ 87(5):940-971

Barton A (1999) Public and private sector accounting - the non-identical twins. Aust Account Rev 9(2):22-31 https://doi.org/ 10.1111/j.1835-2561.1999.tb00105.x

Benito GRG, Goldeng ELB, Grünfeld LA (2008) The performance differential between private and state-owned enterprises: the roles of ownership, management and market structure. J Manag Stud 45(7):1244-1273

Bernoth K, Wolff GB (2008) Fool the markets? Creative accounting, fiscal transparency and sovereign risk premia. Scott J Pol Econ 55(4):465-487

Blejer M, Cheasty A (1991) The measurement of fiscal deficits: analytical and methodological issues. J Econ Lit 29(4):16441678

Bloch, D. and Fall, F. (2015). Government debt indicators: understanding the data. OECD Working Paper, 1228. Available at SSRN: https://ssrn.com/abstract=2673985 or https://doi.org/10.2139/ssrn.2673985

Boycko M, Shleifer A, Vishny RW (1996) A theory of privatization. Econ J 106(435):309-319

Bruton GD, Peng MW, Ahlstrom D, Stan C, Xu K (2015) State-owned enterprises around the world as hybrid organizations. Acad Manag Perspect 29(1):92-114

Cady J (2005) Does SDDS Subscription Reduce Borrowing Costs for Emerging Markets? IMF Staff Paper 52(3):503-517

Cady, J. and Pellechio, A. (2006). Sovereign Borrowing Costs and the IMF's Data Standards Initiative. IMF Working Paper WP/ $06 / 78$

Caprio G, Fiechter JL, Litan RE, Pomerleano M (2004) The future of state-owned financial institutions. The Brookings Institute, Washington, DC

Christofides, Mulder, and Tiffin (2003). The link between adherence to international standards of good practice, foreign exchange spreads, and ratings. IMF Working Paper 03/74

Coccia M (2017) Asymmetric paths of public debts and of general government deficits across countries within and outside the European monetary unification and economic policy of debt dissolution. J Econ Asymmetries 15:17-31

Damgaard, J. and Elkjaer, T. (2017). The global FDI network: searching for ultimate investors. IMF Working Paper, WP/17/258

Dell'Erba S, Hausmann R, Panizza U (2013) Debt levels, debt composition, and sovereign spreads in emerging and advanced economies. Oxf Rev Econ Policy 29(3):518-547

Easterly W, Fisher S (1990) The economics of the government budget constraint. World Bank Res Obs 5(2):127-142

Ebel, R.D. and Yilmaz, S. (2002). On the measurement and impact of fiscal decentralization. World Bank Policy Research Working Paper 2809 
Elgin C, Uras BR (2013) Public debt, sovereign default risk and shadow economy. J Financ Stab 9(4):628-640

Eurostat (2013). European system of national accounts 2010. European Union, 2013

Gelos G, Wei SJ (2005) Transparency and international portfolio holdings. J Financ 9(6):2987-3020

Glennerster R, Shin Y (2003) Is transparency good for you, and can the IMF help? IMF Working Paper, WP/03/132

Goodhart CAE (1975) Problems of monetary management: the UK experience. In: Papers in monetary economics, Volume I,

Reserve Bank of Australia

Hallerberg M, Wolff GB (2008) Fiscal institutions, fiscal policy and sovereign risk premia in EMU. Public Choice 136:379-396 Herrera YM, Kapur D (2007) Improving data quality: actors, incentives, and capabilities. Polit Anal 15(4):365-386

IMF (2011). Public sector debt statistics guide for compilers and users. International Monetary Fund Revised Second Printing 2013

IMF (2014) Government finance statistics manual. International Monetary Fund, Washington

Jaimovich D, Panizza U (2010) Public debt around the world: a new dataset of central government debt. Appl Econ Lett

17(1):19-24 https://doi.org/10.1080/13504850701719785

Kapur D, Lewis JP, Webb R (1997) The World Bank: Its First Half Century. Brookings Institution, Washington, DC

Kotlikoff $L$ (1988) The deficit is not a well-defined measure of fiscal policy. Sci New Ser 241(4867):791-795

Linsi L, Mügge DK (2019) Globalization and the growing defects of international economic statistics. Rev Int Polit Econ 26(3): 361-383 https://doi.org/10.1080/09692290.2018.1560353

Mautz R (1981) Financial reporting: should government emulate business? The chairman of GASBOC recommends probing the significant differences between these entities. J Account (pre-1986) 152(2):53-60

Oates WE (1972) Fiscal Federalism. Harcourt Brace Jovanovich, New York

Oates WE (2008) On the evolution of fiscal federalism: theory and institutions. Natl Tax J 61:313-334

Reinhart CM, Rogoff KS (2010) Growth in a time of debt. Am Econ Rev 100(2):573-578

Rodden J (2004) Comparative federalism and decentralization: on meaning and measurement. Comp Polit 36(4):481-500

Seiferling, M. (2013). Stock-flow adjustments, government's integrated balance sheet and fiscal transparency. IMF Working Papers WP/13/63

Seiferling, M. and Tareq, S. (2015). Fiscal transparency and the performance of government financial assets. IMF Working Papers WP/15/9

Stockman DR (2001) Balanced-budget rules: welfare loss and optimal policies. Rev Econ Dyn 4(2):438-459

Stockman DR (2004) Default, reputation and balanced-budget rules. Rev Econ Dyn 7(2):382-405

Stockman DR (2010) Balanced-budget rules: chaos and deterministic sunspots. J Econ Theory 145(3):1060-1085

Tamegawa K (2016) Rating for government debt and economic stability. J Econ Asymmetries 13:35-44

Tiebout CM (1956) A pure theory of local expenditures. J Polit Econ 64:416-424

UK Office for National Statistics (2018). Wider measures of public sector debt: an update to previous wider measures of government debt articles. ONS. Available at: https:/www.ons.gov.uk/economy/governmentpublicsectorandtaxes/ publicsectorfinance/articles/widermeasuresofpublicsectornetdebt/december2018

United Nations (2009) System of National Accounts 2008. European Communities, International Monetary Fund, Organisation for Economic Co-operation and Development, United Nations and World Bank

\section{Publisher's Note}

Springer Nature remains neutral with regard to jurisdictional claims in published maps and institutional affiliations.

\section{Submit your manuscript to a SpringerOpen ${ }^{\circ}$ journal and benefit from:}

- Convenient online submission

- Rigorous peer review

- Open access: articles freely available online

- High visibility within the field

- Retaining the copyright to your article

Submit your next manuscript at $\boldsymbol{\nabla}$ springeropen.com 